\title{
Rapid ground deformation corresponding to a mining-induced seismic event followed by a massive collapse
}

\author{
Łukasz Rudziński ${ }^{1} \cdot$ Katarzyna Mirek ${ }^{2}$. Janusz Mirek ${ }^{3}$
}

Received: 28 June 2018 / Accepted: 5 December 2018 / Published online: 19 December 2018

(c) The Author(s) 2018

\begin{abstract}
On 17 April 2015, the Wujek/Śląsk underground coal mine in Poland was struck by a strong induced tremor of magnitude M4.0. The event was followed by a massive rock burst and a collapse of tunnels in the vicinity of the hypocentre. The earthquake was widely felt in the densely populated surrounding area. In this paper, we describe a possible connection between seismological parameters, such as the seismic source location and the focal mechanism, and the ground deformation just above the collapsed tunnels a very short time after the event occurred. We have shown that joint seismological and satellite observation can be very valuable and important tools not only to improve the knowledge concerning mining rock bursts and tunnel collapses, but also to find their influences on the ground effects observed on the surface.
\end{abstract}

Keywords Mining seismology $\cdot$ Rock bursts · Ground deformation · Moment tensor · InSAR

\section{Introduction}

Underground mining is a human activity associated with several specific anthropogenic hazards. Issues of great importance in mining areas over the world are seismic activity and rock bursts, i.e. the destruction of mining tunnels during a seismic events. The mining seismicity is also responsible for weak-to-moderate ground shaking, often reported by local residents. Since seismic sources are very shallow (usually not more than $3 \mathrm{~km}$ and very often less than $1 \mathrm{~km}$ ), the vibration caused by even small sources (i.e. magnitudes approximately M3.0 and below) must be considered as potentially hazardous for both surface facilities and mining infrastructures. Another common feature observed on the surface above underground mines is small-to-moderate ground subsidence. It is

Łukasz Rudziński

rudzin@igf.edu.pl

1 Institute of Geophysics, Polish Academy of Sciences, ul. Księcia Janusza 64, Warsaw, Poland

2 AGH University of Science and Technology, al. Mickiewicza 30, Kraków, Poland

3 GAGAT, ul. 20 Straconych 38B, Olkusz, Poland 
generally agreed that both ground shaking (i.e. a seismic event) and local ground failures appear as consequences of mining. While co-seismic vibration effects are more or less similar to what we observe during small-to-moderate natural earthquakes, the shape of the terrain deformations is rather typical for mining areas. The subsidence can be considered as a ground response to the closure of excavated mining panels, usually conducted without any backfill. The ground response and subsidence formed above the mine can last from months to years after the panel has been excavated. These specific issues were also widely observed in two seismically active mining areas in Poland: the Upper Silesian Coal Basin (USCB) — hard coal mine area (Stec 2007) —and the Legnica Głogów Copper District (Lasocki 2005). Both districts are characterized by strong seismic activity, with more than one thousand seismic events above magnitude M1.0 recorded every year. Both districts were also affected by rock bursts and specific surface effects. More than 56,000 tremors of magnitude $M>1.5$ were recorded in the USCB since 1974. The most energetic events result from mining and tectonic stresses and are usually located close to existing tectonic failures. In the 1970s and 1980s, the number of destructive rock bursts yearly exceeded 20 , while in 2000 s, the number decreased to 3 per year. It can be explained by both drop in coal exploitation and increase in rock burst prevention (Stec 2007). The area is characterized by ground subsidence typically form 1.5 up to $5 \mathrm{~m}$. These deformations are associated with mining activity and can be considered as rockmass response due to coal exploitation (Dulias and Kupka 2010).

In this paper, we focus on the strong mining-induced seismic event of M4.0, which occurred on 17 April 2015 in the Wujek/Śląsk coal mine USCB, Poland (Fig. 1). During the earthquake, a massive rock burst occurred, the underground tunnels collapsed, and two miners were buried. Ground shaking was widely reported by the local community in Silesia-Zagłębie Metropolis-a 2.3 million population conurbation (polycentric urban system). The event was considered one of the strongest earthquakes recorded in the USCB area since the beginning of coal exploitation (the end of the nineteenth century). The rescue operation lasted more than 50 days, and the affected part of the mine was closed immediately after the emergency services finished the operation. Since it was impossible to re-open the panel, eventually, the mine was abandoned in March 2018. In this study, we compare the seismological parameters and observation of the surface response to the collapse. We found a very rapid-less than 12 days-ground

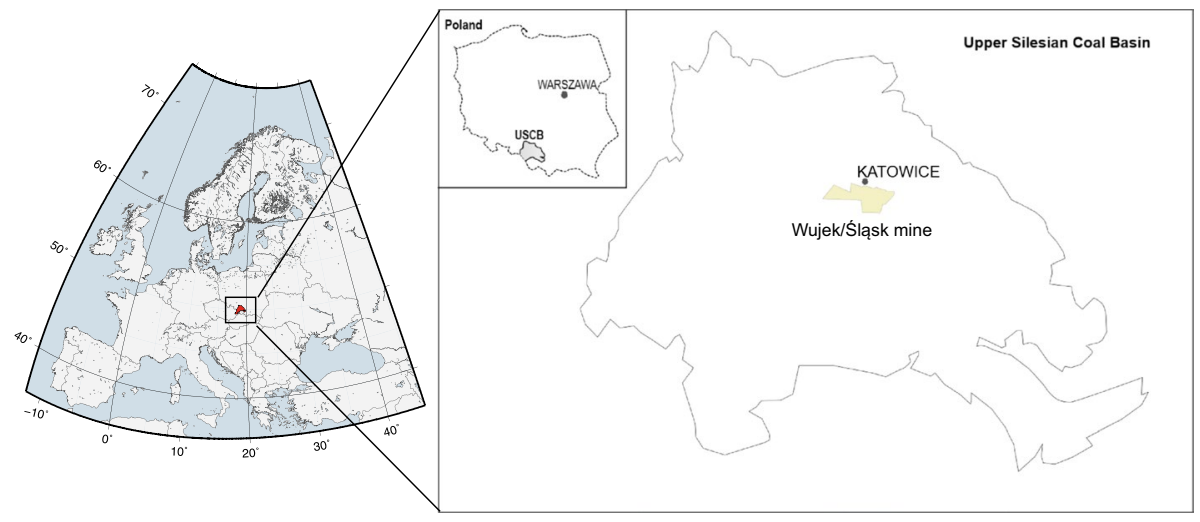

Fig. 1 Location of the upper Silesian coal basin and Wujek/Śląsk coal mine, Poland 
response to the event. The ground deformation corresponds very well with the seismological interpretation.

\section{InSAR method and ground deformation before the event}

Prior studies have shown that satellite radar interferometry (SAR) is a tool that has a wide range of applications in numerous scientific disciplines: from digital elevation models (DEM) through the monitoring of landslides, glaciers, floods and land settling to the study of natural phenomena and vegetation. The method is also widely used in seismology to help determine the epicentre location, fault geometry (e.g. Liu et al. 2004; Karakostas et al. 2016) or impacts of strong earthquakes on the ground shape (e.g. Guerrieri et al. 2010). In mining areas, the technique allows for the tracking of the evolution of subsidence linked to mining fronts and excavations (e.g. Przyłucka et al. 2015; Mirek 2016; Klimczak and Bała 2017), as well as for defining the correlation between ground subsidence and inducing mining seismicity (e.g. Mirek and Mirek 2009, 2016). Typical ground deformation due to exploitation of geo-resources usually lasts for months and can be observed even several years after mining activities have stopped. However, in our studies, we find that subsidence processes caused by a mining collapse can appear after less than 12 days.

The interferometric synthetic aperture radar method (InSAR) is a technique that exploits phase shifts between the radar signals of two satellite SAR images. By processing the phase differences of two images taken during consecutive satellite passes, we obtain a single interferometric image. When recording the radiation reflected from the Earth's surface, information is acquired about the intensity of the reflected radar beams (i.e. the degree to which the waves are absorbed by the Earth's surface) and the phases of these signals at the time of arrival at the receiver. A phase change of $360^{\circ}$ (full cycle) in the SAR image corresponds to half of the signal wavelength. For ERS-1/2, ENVISAT and Sentinel-1A/1B satellites, the SAR device exploits a wavelength of $5.6 \mathrm{~cm}$. By using two SAR images taken at different times, it is possible to find the phase difference for these two signals. The interferometric image obtained from the two SAR images will show altitude changes of the land surface. A phase change of $360^{\circ}$ in the image corresponds to $2.8 \mathrm{~cm}$, which is the altitude change over time between two consecutive SAR images.

In the current study, we used Sentinel-1A (European Space Agency satellite) data acquired in interferometric wide swath mode with a 12 day revisit time and a $5 \times 20 \mathrm{~m}$ ground resolution. The SAR image processing was done in S1TBX software provided by the European Space Agency (https://sentinel.esa.int/web/sentinel/toolboxes/sentinel-1) under the GNU GPL licence. Data processing included the basic steps for interferometry: co-registration of the file from the slave to master, the creation of interferograms and filtration.

Three pairs of SAR images were selected for InSAR processing (Table 1). The interferograms illustrate the deformation before, during and after the 17 April 2015 collapse.

Since the coal extraction in the vicinity of the epicentre started several months before the event, let us first consider the surface deformation just before the earthquake. Figure 2 shows the interferogram obtained from two SAR images: 31 March and 12 April 2015, i.e. 5 days before the event.

It is clear that before the tremor, the trough at the perimeter of which the epicentre was located was in the forming stage (Fig. 2). The subsidence has a length in E-W direction around $800 \mathrm{~m}$ and $\mathrm{N}-\mathrm{S}$ width around $500 \mathrm{~m}$. Let us also notice another smaller ground 
Table 1 Interferometric pairs used in the study

\begin{tabular}{lllll}
\hline & Interferometric pair & Date & $\begin{array}{l}\text { Perpendicu- } \\
\text { lar baseline } \\
(\mathrm{m})\end{array}$ & $\begin{array}{l}\text { Temporal } \\
\text { separation } \\
\text { (days) }\end{array}$ \\
\hline 1 & Master & 31.03 .2015 & 63.87 & 12 \\
& Slave & 12.04 .2015 & & \\
2 & Master & 12.04 .2015 & 64.74 & 12 \\
& Slave & 24.04 .2015 & & \\
& Master & 24.04 .2015 & 208.22 & 12 \\
& Slave & 06.05 .2015 & & \\
\hline
\end{tabular}

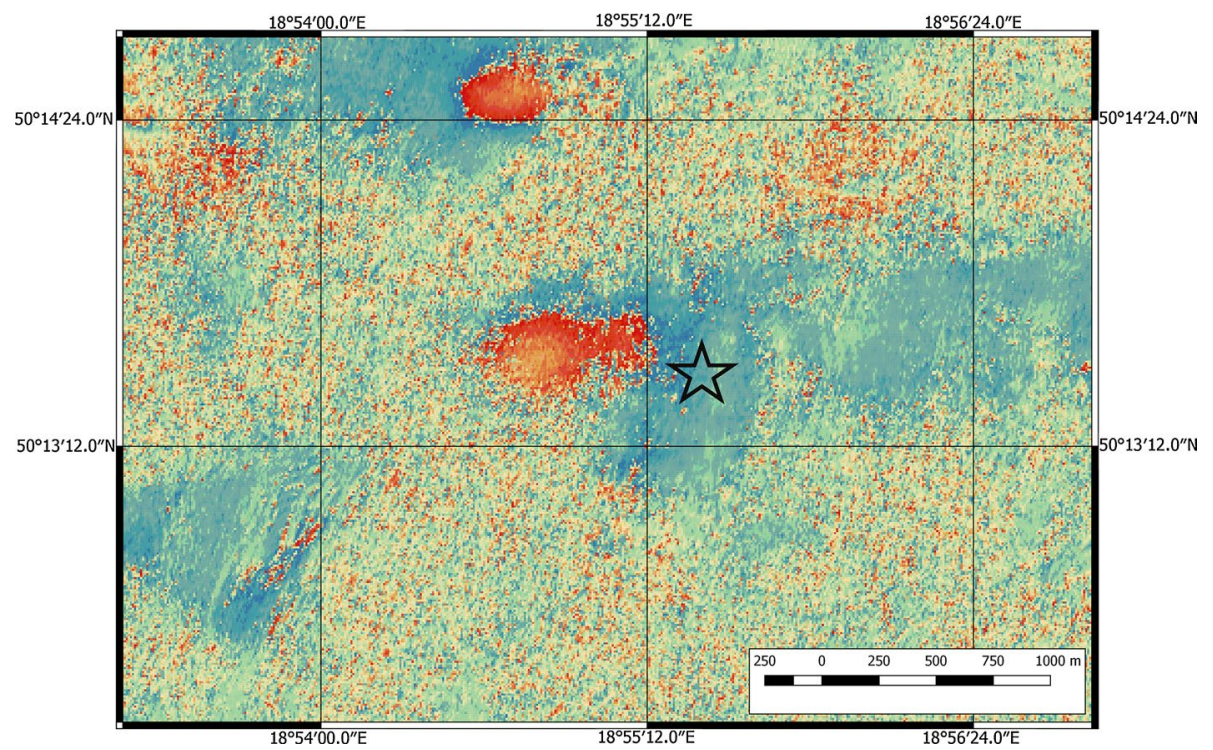

Fig. 2 Interferogram covers the study area just before the 17 April 2015 event (the star denotes the future epicentre). The two SAR images were recorded on 31 March and 12 April 2015

deformation some $750 \mathrm{~m}$ to the north form the future epicentre. This ground feature is a visible continuous subsidence on following interferograms much before March 31 and is typical for deformation associated with mine exploitation in the USCB. The deformation is rather associated with another longwall located in the vicinity to the affected part of the mine. This subsidence is not directly connected to the collapse.

\section{Seismic data analysis and collapse mechanism}

The seismic event occurred in the Wujek/Śląsk coal mine, Poland. According to the European-Mediterranean Seismological Centre (http://www.emsc-csem.org), the earthquake origin time was 17 April 2015 22:16:22.7 UTC (00:16:22.7 CET). The epicentre was located within the coordinates $50.29 \mathrm{~N} 18.92 \mathrm{E}$ at a depth of $10 \mathrm{~km}$ with a magnitude of M4.0. The hypocentre location was also reported by the Central Mining Institute 
(CMI), Katowice, Poland (http://www.grss.gig.eu/en/) at a point of 50.2238N 18.9173E and a depth of $1 \mathrm{~km}$ (fixed at the excavation level according to reported damage) with origin time 22:16:21.8 and magnitude $M_{\mathrm{L}}$ 4.1. The CMI location was obtained through signals recorded by the very local Upper Silesian Regional Seismological Network (USRSN) (Stec 2007).

We upgraded the initial location using the single event location technique and TRMLOC software (Debski 2015; Debski and Klejment 2016) based on signals recorded by the USRSN operated by the CMI in the whole USCB area (IS EPOS 2017). The location app, signals and corresponding metadata are available in the IS-EPOS Platform, the e-platform devoted to anthropogenic hazard analysis, including underground mining (IS EPOS 2017). The final location, together with location errors, is included in Table 2.

Although some of the mining-induced tremors can be modelled similarly to tectonic earthquakes by a double-couple (DC) source model (e.g. Dahm et al. 1999; Richardson et al. 2005), many of the tremors are characterized by strong non-DC components (e.g. Šilený and Milev 2008; Ford et al. 2009), which in particular can be modelled by the isotropic source model for mining earthquakes associated with rock bursts and collapses (e.g. Rudajev and Šilený 1985; Ford et al. 2009; Rudziński et al. 2016). Since the earthquake destroyed (closed) the Wujek/Śląsk mining tunnels, we estimated the source mechanism as a full moment tensor (MT) solution (Jost and Hermann 1989) to verify whether the source was dominated by DC or non-DC effects and how these effects correspond to the surface deformation. The mechanism was estimated using broadband signals recorded at seismological stations belonging to Polish, Czech and Slovak networks (Fig. 3). We used records from seven stations equipped with STS2 seismometers $(120 \mathrm{~s}-50 \mathrm{~Hz})$ and from station OKC working with Güralp CMG3ESP sensors $(60 \mathrm{~s}-50 \mathrm{~Hz})$. The signals and corresponding metadata are available on the ORFEUSEIDA project webpage (http://www.orfeus-eu.org/data/eida/). To obtain real displacements, the data processing consisted of the removal of the station responses and decimation from 20 to $5 \mathrm{~Hz}$.

Several different methods can be used to estimate the full MT. In general, the methods are based on first amplitude or full waveform inversion. While the former approach is less sensitive to signal clipping, an issue often observed during a strong mining tremor recorded by underground networks with low dynamics (Rudziński et al. 2017a), the latter can be used in both the time and frequency domains and is expected to be less sensitive to mismodelling of the velocity structure (Cesca et al. 2006; Domingues et al. 2013). In this paper, we used the full waveform inversion and solved the source mechanism in both domains using the Kiwi tools inversion platform (http://kinherd.org; Heimann 2011) and procedures described by Cesca et al. (2006). The method was already tested for natural earthquakes (Cesca et al. 2013), mining tremors (Sen et al. 2013) and mining collapses in Poland (Rudziński et al. 2016, 2017b; Lasocki et al. 2017). Although the previous study concerning a mining collapse in Poland tested three different velocity models (Rudziński et al. 2016), we used two velocity models, CRUST2.0 Bassin et al. (2000) and Grad et al. (2003), just to ensure the quality of the regional MT solution.

Table 2 The 17 April 2015 earthquake epicentre coordinates and corresponding errors

\begin{tabular}{lll}
\hline Latitude & Longitude & Depth (m) \\
\hline $50.2255 \mathrm{~N}$ & $18.9237 \mathrm{E}$ & 995 \\
$220 \mathrm{~m}$ & $175 \mathrm{~m}$ & $317 \mathrm{~m}$ \\
\hline
\end{tabular}




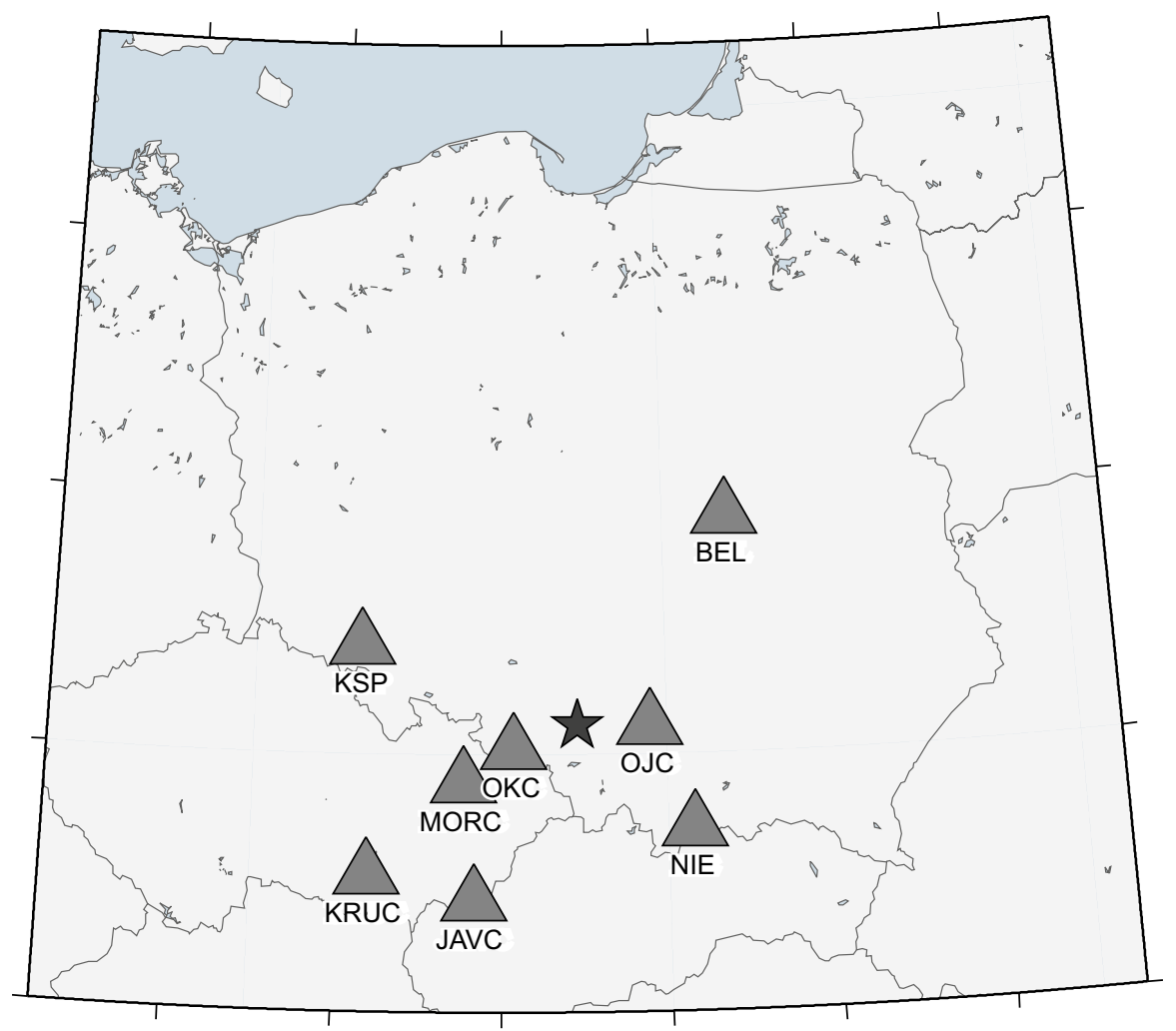

Fig. 3 Epicentre (star) and stations (triangles) used to estimate the source mechanism of the 17 April 2015 earthquake

The full MT inversions were done with signals filtered between 0.13 and $0.16 \mathrm{~Hz}$. We inverted the real and synthetic data calculated for both velocity structures in both the frequency and time domains. After the inversion, the results were completed and contained the full MT components, seismic moment and corresponding moment magnitude $M_{\mathrm{w}}$. Since the inversions with both velocity models led to almost identical results, we decided that the final solution was characterized by the Grad et al. (2003) model, which yielded a smaller misfit. The final MT and its decomposition into isotropic, compensated linear

Table 3 Final MT components and MT decomposition: ISO, isotropic term; CLVD, compensated linear vector dipole; DC, double couple

\begin{tabular}{|c|c|c|c|c|c|c|c|c|c|c|}
\hline \multicolumn{6}{|c|}{ Moment tensor (MT) components } & \multirow[t]{2}{*}{$\begin{array}{l}\text { Seismic moment, } \\
M_{0}(\mathrm{Nm})\end{array}$} & \multirow{2}{*}{$\begin{array}{l}\text { Moment } \\
\text { magnitude, } \\
M_{\mathrm{w}}\end{array}$} & \multicolumn{3}{|c|}{$\begin{array}{l}\text { MT decomposition } \\
\text { components }\end{array}$} \\
\hline m11 & $\mathrm{m} 22$ & $\mathrm{~m} 33$ & $\mathrm{~m} 12$ & $\mathrm{~m} 13$ & $\mathrm{~m} 23$ & & & ISO & CLVD & DC \\
\hline $\begin{array}{c}-2.4 \times \\
10^{14}\end{array}$ & $\begin{array}{c}-2.0 \times \\
10^{14}\end{array}$ & $\begin{array}{r}-4.1 \times \\
10^{14}\end{array}$ & $\begin{array}{c}-0.01 \times \\
10^{14}\end{array}$ & $\begin{array}{r}-0.6 \times \\
10^{14}\end{array}$ & $\begin{array}{c}-0.1 \times \\
10^{14}\end{array}$ & $4.28 \times 10^{14}$ & 3.7 & $-66 \%$ & $28 \%$ & $6 \%$ \\
\hline
\end{tabular}

The seismic moment $M_{0}$ and corresponding moment magnitude $M_{\mathrm{w}}$ are also included 
vector dipole (CLVD) and DC parts are shown in Table 3. Such MT decomposition is often used in mining seismology because of its possible interpretations (Hasegawa et al. 1989).

Note that the source mechanism (Table 3 ) is dominated by a very high (more than $60 \%$ ) implosive component. This kind of result is not exceptional for mining collapses and is similar to the solutions reported earlier for Polish copper mines (Rudziński et al. 2016, 2017b; Lasocki et al. 2017). The source model represented by such MT is similar to the so-called tabular cavity collapse (Talebi and Côté 2005; Rudziński et al. 2016), which is the model of a mining collapse interpreted as a closure of an underground tunnel with associated roof collapse, footwall uplift and sidewall failure. According to the underground inspection, these kinds of damage were observed after the tremor. It is also very likely that such a source can be responsible for the terrain deformation just above the affected tunnels.

We have also noticed a small differences among magnitude reported by EMSC (body wave magnitude $\mathrm{mb}), \mathrm{CMI}\left(M_{\mathrm{L}}\right)$ and our result. These differences at least partially can be explained by different methods used. While the local magnitude describes the seismic energy recorded on local distances in spectrum limited by the Wood-Anderson (W-A) instrument, our moment magnitude corresponds only to the low-frequency part of seismic spectrum recorded on regional distances in frequency between 0.13 and $0.16 \mathrm{~Hz}$. In other words, the $M_{\mathrm{L}}$ and $M_{\mathrm{w}}$ were estimated in different parts of the spectrum. The difference between $\mathrm{mb}$ and $M_{\mathrm{w}}$ more likely can be explained by the difference in depth between automatic location (EMSC) and location presented in this study.

\section{Ground deformation after the event}

Since the earthquake, rock burst and collapse occurred during the time between two SAR images, the possible ground deformation during this period above the mining area can be considered as nearly "co-seismic" effects, directly caused by the event. To study these effects, we used the pair of SAR images dated April 12 (5 days before the event) and April 24 (7 days after the tremor). The 12-day interval differential interferogram (Fig. 4a) shows a distinctive concentric feature, which indicates a subsidence trough. The subsidence pattern shows one cycle of deformation corresponding to approximately $2.8 \mathrm{~cm}$ of subsidence. The terrain features also correspond very well with both the epicentre location and the collapse source model (Fig. 4b).

Now, let us consider the interferogram obtained by the next interferometric pair (Table 1) dated 24 April and 6 May 2015. From Fig. 5, it is clear that the last interferogram indicates a stabilization of the surface above the epicentre. Therefore, we conclude that most of the subsidence observed in the InSAR images was likely due to the mine collapse on 17 April 2015. The surface features observed after April 24 strongly suggest that this rapid deformation can be treated as a "co-seismic" ground response to the earthquake.

\section{Conclusions}

Rock bursts are considered the most dangerous events associated with mining seismic activity. Usually, the rock bursts are responsible for strong ground shaking, which is often reported by the local community. On the other hand, it was not obvious that the induced events were also responsible for the very rapid ground deformation. In the current study, 

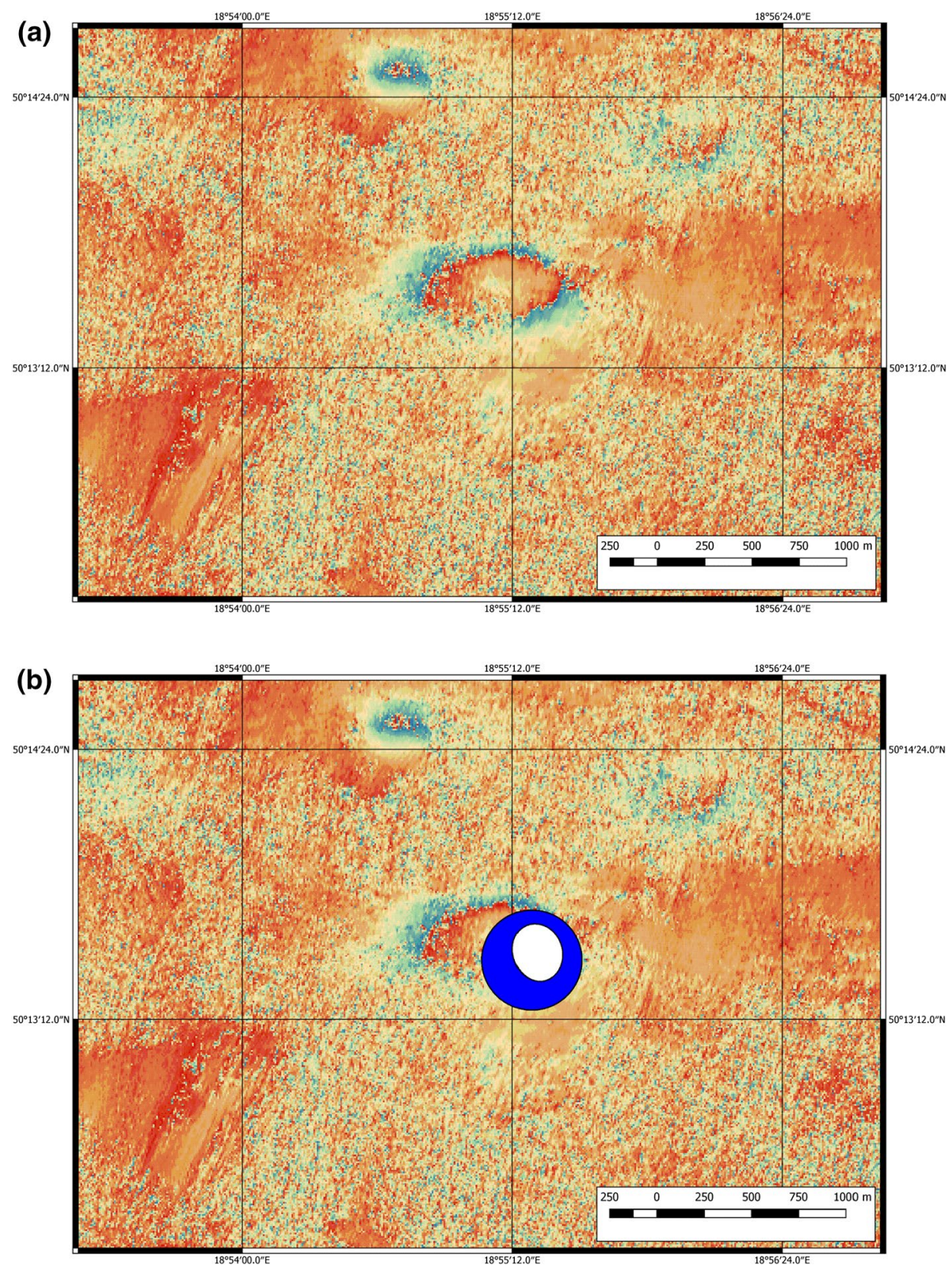

Fig. 4 a Interferograms of the Wujek/Śląsk mining area between 12 April and 24 April 2015. b The same interferograms together with the source mechanism corresponding to the final MT (Table 3). The location of the focal sphere in the image corresponds to the epicentre, while the size of the beach ball corresponds to the location errors (Table 2) 


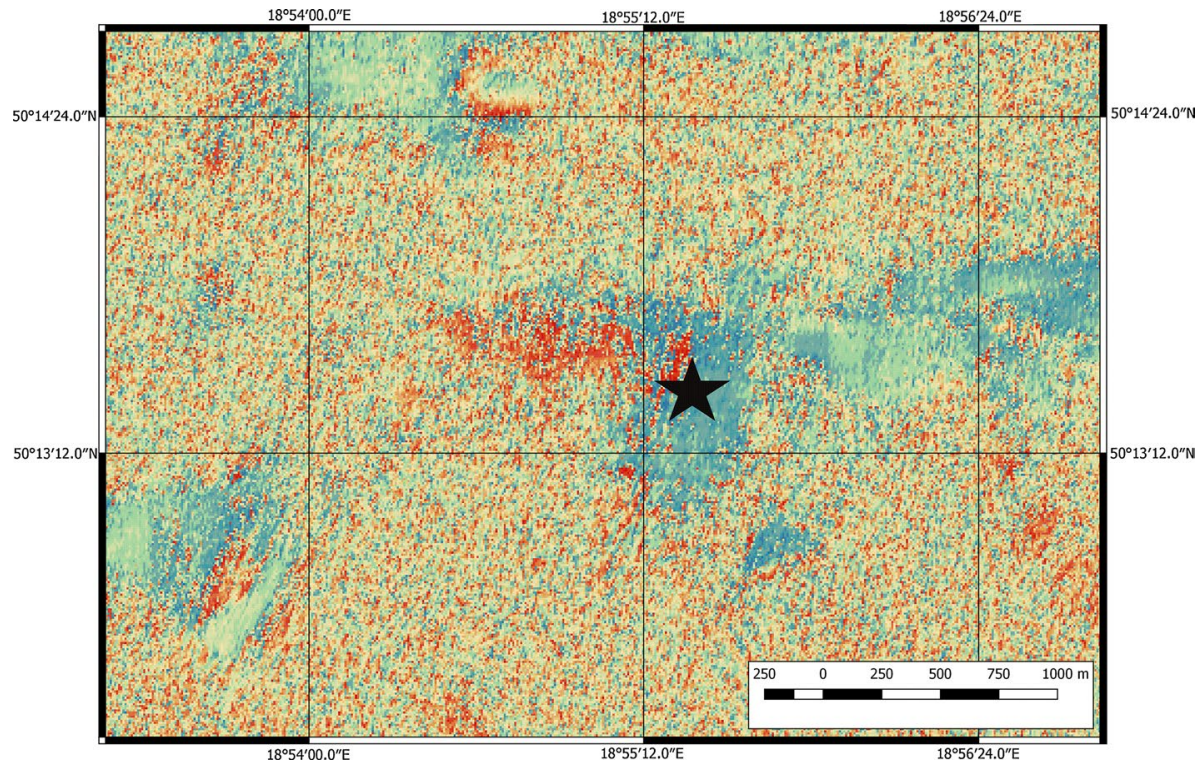

Fig. 5 Ground deformation observed between 24 April and 6 May 2015. The epicentre is denoted by the black star

we show that the combination of InSAR observations and simple seismological analysis can provide important insights into mine collapses. The presented example shows a very good agreement between the seismological results and the terrain features observed just above the epicentre a relatively short time after the earthquake. We noted that routine monitoring of the land surface subsidence via satellite InSAR data could provide constraining information about future mine collapses, especially over poorly instrumented areas. The satellite observation should be combined with other types of monitoring, especially seismological and strong motion observations. The combined seismological and ground deformation monitoring should be recommended as an important solution in any mining areas with a high likelihood of rock burst hazards.

Acknowledgements Łukasz Rudziński has been supported within statutory activities Number 3841/E-41/S/2018 of the Ministry of Science and Higher Education of Poland as well as the EPOS Implementation Phase (EPOS IP) project funded by the EU Horizon 2020 programme under Grant Agreement No. 676564 and National Research Funds in the scope of the co-financed international projects framework (Agreement No: 3504/H2020/2017/2) financed by Polish Ministry of Science and Higher Education. Katarzyna Mirek has been supported by the AGH University of Science and Technology in Krakow, Project No. 11.11.140.613. Some figures were prepared with the Generic Mapping Tools (GMT) software (Wessel and Smith 1998). We wish to express our gratitude to the Editor. The authors are also indebted to the anonymous reviewers for their valuable comments.

Open Access This article is distributed under the terms of the Creative Commons Attribution 4.0 International License (http://creativecommons.org/licenses/by/4.0/), which permits unrestricted use, distribution, and reproduction in any medium, provided you give appropriate credit to the original author(s) and the source, provide a link to the Creative Commons license, and indicate if changes were made. 


\section{References}

Bassin C, Laske G, Masters G (2000) The current limits of resolution for surface wave tomography in North America. Eos Trans. AGU 81(48) (Fall Meet. Suppl.), Abstract S12A-03

Cesca S, Buforn E, Dahm T (2006) Moment tensor inversion of shallow earthquakes in Spain. Geophys J Int. https://doi.org/10.1111/j.1365-246x.2006.03073.x

Cesca S, Rohr A, Dahm T (2013) Discrimination of induced seismicity by full moment tensor inversion and decomposition. J Seismol 17(1):147-163. https://doi.org/10.1007/s10950-012-9305-8

Dahm T, Manthei G, Eisenblätter J (1999) Automated moment tensor inversion to estimate source mechanisms of hydraulically induced microseismicity in salt rock. Tectonophysics 306(1):1-17. https://doi. org/10.1016/s0040-1951(99)00041-4

Debski W (2015) Using meta-information of a posteriori Bayesian solutions of the hypocenter location task for improving accuracy of location error estimation. Geophys J Int 201(3):1399-1408. https://doi. org/10.1093/gji/ggv083

Dębski W, Klejment P (2016) The new algorithm for fast probabilistic hypocenter locations. Acta Geophys 64(6):2382-2409. https://doi.org/10.1007/978-3-319-71788-3_15

Domingues A, Custodio S, Cesca S (2013) Waveform inversion of small to moderate earthquakes located offshore southwest Iberia. Geophys J Int. https://doi.org/10.1093/gji/ggs010

Dulias R, Kupka R (2010) Impact of mining on the relief of Katowice. In: Andrejczuk et al. (eds) Kształtowanie środowiska geograficznego i ochrona przyrody na obszarach uprzemysłowionych i zurbanizowanych, Silesia University in Katowice, Katowice-Sosnowiec 2010, pp 26-31(english abstract)

Ford SR, Dreger DS, Walter WR (2009) Identifying isotropic events using a regional moment tensor inversion. J Geophys Res 114:B01306. https://doi.org/10.1029/2008jb005743

Grad M, Jensen SL, Keller GR, Guterch A, Thybo H, Janik T, Tiira T, Yliniemi J, Luosto U, Motuza G et al (2003) Crustal structure of the trans-European suture zone region along POLONAISE'97 seismic profile P4. J Geophys Res 108:12. https://doi.org/10.1029/2003jb002426

Guerrieri L, Baer G, Hamiel Y, Amit R, Blumetti AM, Comerci V, Manna PD, Michetti AM, Salamon A, Mushkin A, Sileo G, Vittori E (2010) InSAR data as a field guide for mapping minor earthquake surface ruptures: ground displacements along the Paganica fault during the 6 April 2009 L'Aquila earthquake. J Geophys Res 155(B12):2010

Hasegawa HS, Wetmiller RJ, Gendzwill DJ (1989) Induced seismicity in mines in Canada-an overview. Pure Appl Geophys 129:423-453

Heimann S (2011) A robust method to estimate kinematic earthquake source parameters. Dissertation, University of Hamburg, Germany

IS EPOS (2017) Episode: USCB. https://tcs.ah-epos.eu/\#episode:USCB. https://doi.org/10.25171/instg eoph_pas_isepos-2017-007

Jost ML, Hermann RB (1989) A student's guide to and review of moment tensors. Seismol Res Lett 60:37-57. https://doi.org/10.1785/gssrl.60.2.37

Karakostas V, Mirek K, Mesimeri M, Papadimitriou E, Mirek J (2016) The aftershock sequence of the 2008 Achaia, Greece, earthquake: joint analysis of seismicity relocation and persistent scatterers interferometry. Pure Appl Geophys. https://doi.org/10.1007/s00024-016-1368-y

Klimczak M, Bała J (2017) Application of the Hough transform for subsidence troughs detection in SAR images. In: 17th International multidisciplinary scientific geoconference SGEM 2017. www.sgem. org, SGEM2017 conference proceedings, ISBN 978-619-7408-01-0/ISSN 1314-2704, 29 June-5 July, 2017, Vol 17(21):819-826. https://doi.org/10.5593/sgem2017/21/s08.104

Lasocki S (2005) Probabilistic analysis of seismic hazard posed by mining induced events. In: Potvin Y, Hudyma M (eds) Controlling seismic risk, proceedings of the 6th international symposium on rockburst and seismicity in mines, Nedlands, Australia 9-11 March 2005. Australian Centre for Geomechanics, pp 151-156

Lasocki, S, Orlecka-Sikora B, Mutke G, Pytel W, Rudziński Ł, Markowski P, Piasecki P (2017) A catastrophic event in Rudna copper-ore mine in Poland on 29 November, 2016: what, how and why. In: Vallejos JA (ed) Rock mass response to mining and underground construction, proceedings of the 9th international symposium on rockburst and seismicity in mines, November 15-17, Santiago, Chile, Editec S.A., Santiago, Chile, pp 316-324

Liu GX, Ding XL, Li ZL, Li ZW, Chen YQ, Yu SB (2004) Pre- and co-seismic ground deformations of the 1999 Chi-Chi, Taiwan earthquake, measured with SAR interferometry. Comput Geosci 30(4):333-343 
Mirek K (2016) Monitoring land subsidence over mining areas with Sentinel-1 differential SAR interferometry. In: Ouwehand L (ed) Proceedings of ESA living planet symposium, Prague 9-13 May 2016, SP-740

Mirek K, Mirek J (2009) Non-parametric approximation used to analysis of PSinSAR ${ }^{\mathrm{TM}}$ data of Upper Silesian Coal Basin, Poland. Acta Geodynamica et Geomaterialia 6(4):405-409

Mirek K, Mirek J (2016) Observation of underground exploitation influence on a surface in Budryk, Sośnica, and Makoszowy coal mine area. Pol J Environ Stud 25(5A):57-61

Przyłucka M, Herrera G, Graniczny M, Colombo D, Bejar-Pizarro M (2015) Combination of conventional and advanced DInSAR to monitor very fast mining subsidence with TerraSar-X data: Bytom City (Poland). Remote Sens 7:5300-5328

Richardson E, Nyblade AA, Walter WR, Rodgers AJ (2005) Source characteristics of mining-induced seismicity from moment tensor analysis and spatio-temporal relationship. In: Potvin Y, Hudyma $\mathrm{M}$ (eds) Controlling seismic risk, proceedings of the 6th international symposium on rockburst and seismicity in mines, Nedlands, Australia 9-11 March 2005 Australian Centre for Geomechanics, pp $123-127$

Rudajev V, Šilený J (1985) Seismic events with non-shear component II. Rock bursts with implosive source component. Pure Appl Geophys 123:17-25

Rudziński Ł, Cesca S, Lizurek G (2016) Complex rupture process of the March 19, 2013, Rudna mine (Poland) induced seismic event and collapse in the light of local and regional moment tensor inversion. Seismol Res Lett. https://doi.org/10.1785/0220150150

Rudziński Ł, Mirek J, Lizurek G (2017a) Identification of seismic doublets occurred on Rudna mine, Poland. Acta Geophysica 65(2):287-298. https://doi.org/10.1007/s11600-017-0034-9

Rudziński Ł, Cesca S, Talaga A, Koziarz E (2017b) Complex Mechanism of Rockburst observed on Polish Copper Mines, In: Vallejos JA (ed) rock mass response to mining and underground construction, proceedings of the 9th international symposium on rockburst and seismicity in mines, November 15-17, Santiago, Chile, Editec S.A., Santiago, Chile, pp 87-92

Sen AT, Cesca S, Bischoff M, Meier T, Dahm T (2013) Automated full moment tensor inversion of coal mining-induced seismicity. Geophys J Int 195:1267-1281. https://doi.org/10.1093/gji/ggt300

Šilený J, Milev A (2008) Source mechanisms of mining induced seismic events-resolution of double couple and non double couple models. Tectonophysics 456(2008):3-15. https://doi.org/10.1016/j. tecto.2006.09.021

Stec K (2007) Characteristics of seismic activity of the Upper Silesian Coal Basin in Poland. Geophys J Int 168(2):757-768. https://doi.org/10.1111/j.1365-246x.2006.03227.x

Talebi S, Côté M (2005) Implosional focal mechanisms in a hardrock mine, In: Potvin Y, Hudyma M (eds) Controlling seismic risk, proceedings of the 6th international symposium on rockburst and seismicity in mines, Nedlands, Australia 9-11 March 2005 Australian Centre for Geomechanics, pp 113-121

Wessel P, Smith WHF (1998) New, improved version of generic mapping tools released. EOS Trans AGU 79:579

Publisher's Note Springer Nature remains neutral with regard to jurisdictional claims in published maps and institutional affiliations. 